\title{
A DIÁK KIÉGÉS KÉRDÖÍV SZERKEZETÉNEK VIZSGÁLATA MAGYAR MINTÁN
}

\author{
JAGODICS BALÁZS ${ }^{1,2^{*}}$ - KÓRÓDI KITTI ${ }^{1}$ - DR. SZABÓ ÉVA ${ }^{1}$ \\ ${ }^{1}$ SZTE BTK Pszichológiai Intézet, Szociál- és Fejlôdéspszichológiai Tanszék, \\ Szeged, Magyarország \\ ${ }^{2}$ PTE BTK Pszichológia Doktori Iskola, Szociálpszichológia Doktori Program, \\ Pécs, Magyarország \\ E-mail: balazs.jagodics@gmail.com
}

Benyújtva: 2019. június 17. - Elfogadva: 2021. március 26.

Háttér és célkitûzések: A felnôttek munkahelyi kiégésének vizsgálata mellett egyre nagyobb szerepet kap a problémakör iskolai vonatkozásának feltárása is. Tanulmányunk célja a Salmela-Aro és munkatársai (2008, 2009) által kidolgozott Diák Kiégés Kérdốiv hazai változatának tesztelése volt.

Módszer: Magyar általános és középiskolás, 13-18 éves $(M=15,3$ év; $S D=2,01)$ diákokból álló mintán $\left(N_{\text {átalatanos issola }}=337 ; N_{\text {közópissola }}=738\right)$ ellenôriztük a kérdốív szerkezetét, belsố konzisztenciáját, illetve a diák kiégés kapcsolatát demográfiai és pszichológiai jellegú változókkal.

Eredmények: A feltáró és megerôsítô faktorelemzés szerint az eredetivel megegyezô, háromfaktoros struktúra jellemző a kérdốtvre, amelyet az érzelmi kimerülés, a cinizmus és az alkalmatlanságérzés alskálák alkotnak. A kiégés kérdốiven a nemek között nem találtunk különbséget, iskolatípus tekintetében pedig csak a cinizmus alskálán különböztek az általános és középiskolás diákok pontszámai. A tanulmányi eredmény negatív összefüggést mutatott a kiégéssel, hasonlóan az önértékeléshez, az iskolai kötôdéshez és a közelítô-elsajátító célorientációhoz. Az elkerülố célorientáció gyenge pozitív együtt járást mutatott a kiégéspontszámmal. A hierarchikus regresszióelemzés szerint a Diák Kiégés Kérdốv alskálái a célorientációs kérdốv dimenzióival együtt az önértékelés varianciájának 50,3\%-át képesek megmagyarázni.

Következtetések: Az eredmények alapján kialakitott nyolctételes kérdốv alkalmasnak tünik a diák kiégés mérésére, illetve azon belül az érzelmi kimerülés, a cinizmus és az alkalmatlanságérzés tüneteinek elkülönitésére. Ugyanakkor a Cronbach-alfa-mutatók alapján utóbbi két alskála belsố megbizhatósága csak elfogadható mértékü, emiatt a kérdốvet egydimenziós skálaként ajánljuk használni. A kérdốv alkalmas lehet további feltáró kutatásokban való alkalmazásra, illetve hasznos segédeszköz lehet az iskolapszichológiai gyakorlat számára is.

Kulcsszavak: diák kiégés, önértékelés, célorientáció, iskolai kötôdés

" Levelezố szerzô

(C) 2021 A szerzố(k) 


\section{BEVEZETÉS}

Az iskola nem csak a pedagógusok számára jelent munkahelyet. A diákok a statisztikák szerint átlagosan 7-8 órát töltenek az intézményekben, ráadásul nem pusztán jelen vannak, de folyamatos teljesítményhelyzeteket és stresszt élnek meg, tartós érzelmi és mentális terhelésnek vannak kitéve. Rendszeresen ellenőrzik a teljesítményüket, folyamatos társas alkalmazkodási elvárásoknak kell megfelelniük, hosszú idôn keresztül kell intenzíven koncentrálniuk. Sôt, a napi oktatási teher mellett még a délutáni idôszakban is folytatniuk kell a tanulást, így viszonylag kevés idejük marad regenerálódásra, pihenésre (Martonné és Kollár, 2001). Emellett az érzelmi megterhelés is jelentôsnek tekinthető, fơként ha figyelembe vesszük az iskolai zaklatás sokakat érintố problémáját (Várnai és mtsai, 2018). Ebben az értelemben az iskolát az ó esetükben tekinthetjük a munkahely analógiájának. Így joggal merül fel az a lehetôség, hogy a felnôttek körében azonosított munkahelyikiégés-szindróma már a diákok körében is megjelenhet. A nemzetközi szakirodalomban az ezredforduló óta jelennek meg olyan kutatási beszámolók, amelyek ezt a problémakört érintik (ld. Schaufeli, Martínez, Pinto, Salanova és Bakker, 2002). A hazai kutatások áttekintése azt mutatja, hogy a diákok kiégésének feltárása még nem került a kutatások fókuszába. Ennek részben az lehet az oka, hogy jelenleg csupán egy magyar nyelven elérhetô méróeszköz áll a szakemberek rendelkezésére (Hazag, Major és Ádám, 2010), amely elsôsorban az egyetemi hallgatók körében megjelenô kiégés azonosítására alkalmas. Jelen tanulmány célja ezért kettôs. Egyrészt felhívni a figyelmet arra, hogy a kiégés már a középiskolás korosztály körében is jelen lévô probléma, amelynek hazai kutatása nemcsak elméleti, de gyakorlati szempontból is idôszerú és indokolt. Másrészt szeretnénk bemutatni a School Burnout Inventory (Salmela-Aro és mtsai, 2008) magyar változatának pszichometriai jellemzőit, és az adaptált kérdôível végzett elsô vizsgálatok eredményeit.

\section{A kiégésszindróma általános jellemzése}

A kiégésszindróma kutatása az egészségügyi dolgozók hosszú távú stresszre és leterheltségre adott válaszainak vizsgálatából indult ki. Elsôként Freudenberger (1974) írta le burnoutszindrómaként azt a pszichológiai állapotot, mely a munkahelyen tapasztalt stressz következtében alakul ki, és fôként kimerültséggel, motiválatlansággal, a negatív érzelmek túlsúlyával jellemezhetô. A krónikus fáradtság és a stresszbôl fakadó legyengültség miatt a kiégésszindrómától szenvedôk esetében gyakoribb a betegségek kialakulása is (Freudenberger, 1974). Emellett a burnoutszindrómában érintett személyek érzelmi reakciói hevesebbek, gyakrabban tapasztalnak negatív érzelmeket és haragot, türelmetlenebbek, amit környezetük fôként a konfliktushelyzetekben tapasztal meg (Maslach és Goldberg, 1998), ami hosszabb távon a kapcsolatok romlásához vezethet, ami tovább növeli a munkahelyi stresszt, így erôsítheti a kiégés érzését. A kiégésszindróma vizsgálata alapján három fô tünetcsoport különíthetô el: a személyes teljesítmény csökkenése, az érzelmi kimerülés és a deperszonalizáció (Maslach, 1982; Maslach és Jackson, 1986). 
Habár az elsô beszámolók elsôsorban egészségügyi területen dolgozók esetében írták le a kiégésszindrómát, ma már jelentôs irodalma van a burnoutszindróma vizsgálatának pedagógusok körében is, akiket szintén gyakran érintenek az említett tünetek (Caroli és Sagone, 2012; Skaalvik és Skaalvik, 2009, 2014; Szabó és Jagodics, 2016).

\section{Kiégésszindróma az iskolában}

A kiégésszindróma kutatásának áttekintésébôl látható, hogy az elmúlt évtizedekben fokozatosan megváltozott a jelenség kutatásának fókusza. A kezdeti, egészségügyi szakembereket érintô problémából mára általánossá vált a burnoutszindróma széles réteget érintố munkahelyi-életvezetési nehézségként való kezelése. Talán ennek is köszönhetô, hogy az Egészségügyi Világszervezet (WHO) az elmúlt idôszakban hivatalosan is egészségügyi rendellenességnek minôsítette (World Health Organisation, 2018). A kiégés kutatása sokáig kizárólag a probléma felnôtteket érintô vetületeire fókuszált, holott nyilvánvaló, hogy a diákokat is hasonló megterhelô életmód jellemzi, és feltehetôen ôk sem tudnak minden esetben hatékonyan megküzdeni a krónikus „munkahelyi” stresszel. Az elmúlt évtizedben kezdtek megjelenni olyan vizsgálatok, amelyek a burnoutszindróma elméleti kereteit kiterjesztették az oktatási intézményekben tanulókra is. Elôször az egyetemi hallgatók kiégését vizsgálták (Schaufeli és mtsai, 2002), majd a jelenség elôfordulását általános és középiskolás diákoknál is megfigyelték (Kiuru, Aunola, Nurmi, Leskinen és Salmela-Aro, 2008). A kiégés iskolai vonatkozásainak vizsgálatát az indokolta, hogy a diákok és egyetemi hallgatók életében hasonló funkciót lát el az intézményesített oktatás, mint a felnôttek életében a munkahely. Emiatt az iskolai környezetben a diákokat érô pszichológiai hatások is nagyrészt hasonlóak ahhoz, mint amiket a felnôttek tapasztalnak munkavégzésük közben. Az iskolásszerep is kötelezettségekkel és feladatokkal jár, amelyek hosszú távon ugyanúgy leterhelik a diákokat, mint a munkavégzés a felnốtteket (Kiuru és mtsai, 2008; Salmela-Aro, Kiuru, Pietikäinen és Jokela, 2008). Emellett számos érzelmi nehézséggel, konfliktussal is szembe kell nézniük mind a diáktársakkal, mind a pedagógusokkal való együttmúködés során. Különösen veszélyeztetô szituációt eredményez ebbôl a szempontból az iskolai zaklatás, amely az érintettek, de sok esetben a szemlélôdôk körében is fokozza a szorongást (Várnai és mtsai, 2018). Erre utal az is, hogy a diákok kiégésénél a felnôttekéhez hasonló tüneteket azonosítottak, azaz az iskolai túlterhelés miatt kialakuló érzelmi kimerülést, az iskolához füzôdô cinikus és közönyös viszonyt, ami a deperszonalizációnak feleltethetố meg, valamint a feladatokkal kapcsolatos inkompetenciaérzést (Salmela-Aro és mtsai, 2008).

Az iskoláskorú gyermekek és serdülôk mentálhigiénés állapotával foglalkozó felmérések szerint gyakoriak a szorongással, illetve kimerültséggel járó tünetek ebben a korcsoportban. Az Amerikai Pszichológiai Társaság (2014) felmérése szerint az USA-ban az amerikai tinédzserek körülbelül egyharmadát érintik a kimerültséggel és leterheltséggel kapcsolatos tünetek, ezt az eredményt erôsítették meg az Egészségügyi Világszervezet vonatkozó statisztikai adatai is (Inchley és mtsai, 2016). Európában kevés átfogó kutatásról tudunk, de a kifejezetten iskolai kiégésre vonatkozó felmérések szerint a finn diákok 10\%-a szenved a kiégés súlyos tüneteitôl (Salmela-Aro és Newman, 2005; idézi: Salmela-Aro és mtsai, 2008). 


\section{A diák kiégés mérésére épülō méröeszközök}

Az iskolai kiégés mérésére, a felnôttekéhez hasonlóan, önbevalláson alapuló skálákat használnak. Ezek közül leggyakrabban a Maslach-féle Kiégés Leltár Diák Változatával (Maslach Burnout Inventory - Student Survey; MBI-SS; Schaufeli és mtsai, 2002), valamint a Salmela-Aro és munkatársai (2008; 2009) által kidolgozott Diák Kiégés Kérdôível (School Burnout Inventory) dolgoznak a kutatók.

A Maslach-féle Kiégés Leltár Diák Változata egy 16 tételes méróeszköz, amely a munkahelyi kiégés általános feltárására alkalmas MBI-GS (Maslach Burnout Inventory - General Survey; Schaufeli, Leiter, Maslach és Jackson, 1996) tanulási környezetre módosított változata. A méróeszköz tételei három alskálát alkotnak: a kimerülés, a cinizmus és a hatékonyság területén mérik fel a kiégés tüneteit. A méróeszköz szerkezetét és belsố megbízhatóságát tekintve jó mutatókkal bír (Schaufeli, Martínez, Pinto, Salanova és Bakker, 2002).

A Salmela-Aro és munkatársai által kifejlesztett Diák Kiégés Kérdôív (School Burnout Inventory) a Bergen-féle Kiégés Kérdőívból (Näätänen, Aro, Matthiesen és Salmela-Aro, 2003) származik, amely a felnôttek munkahelyi kiégésének elterjedt mérôeszköze. A kérdôív kilenc tételbôl álló önkitöltéses kérdôív, amely tartalmilag a faktorelemzés szerint három alskálára osztható: érzelmi kimerülés, cinizmus és alkalmatlanságérzés. Ez a felosztás megfeleltethetố a munkahelyi kiégés tüneteinek meghatározásánál elterjedten használt érzelmi kimerülés, deperszonalizáció, teljesítménycsökkenés dimenzióknak (Maslach, 1982). A Diák Kiégés Kérdôívet számos kutatásban használták a faktorszerkezet és a belsố megbízhatóság tesztelésével. A legtöbb esetben a faktorszerkezet jó illeszkedésérôl és megfelelô reliabilitásáról számoltak be a kutatások (Fiorilli, De Stasio, Di Chiacchio, Pepe és Salmela-Aro, 2017; Hietajärvi, Salmela-Aro, Tuominen, Hakkarainen és Lonka, 2019; Räisänen, Postareff, Mattsson és Lindblom-Ylänne, 2018; Seibert, Bauer, May és Fincham, 2017; Sorkkila, Tolvanen, Aunola és Ryba, 2019; Wang, Kiuru, Degol és Salmela-Aro, 2018). Azonban bizonyos esetekben a kutatók szükségesnek látták a kérdőív szerkezetének felülvizsgálatát, például az alkalmatlanságérzés alskála kihagyását az idetartozó tételek alacsony faktortöltése miatt (Herrmann, Koeppen és Kessels, 2019). A statisztikai adatok mellett a szerzôk döntését az az elméleti megállapítás is alátámasztja, hogy a kiégésszindróma magját az érzelmi kimerülés és a cinizmus alkotja (Purvanova és Muros, 2010). A Maslach Kiégés Leltár Diák Változatával (Maslach Burnout Inventory - Student Survey; MBI-SS; Schaufeli és mtsai, 2002) összevetve a Diák Kiégés Kérdôív alskálái közepes, illetve erôs korrelációt mutattak egy korábbi longitudinális vizsgálat során (Seibert és mtsai, 2017).

Magyar nyelven elérhetô, kifejezetten az iskolás diákok kiégésének mérésére alkalmas kérdőívrôl nincs tudomásunk. Hasonló megközelítést alkalmazó mérôeszköz a Maslach Kiégés-teszt Hallgatói Változata (Hazag, Major és Ádám, 2010), amely felsôoktatásban tanuló diákok esetében mutat jó megbízhatóságot az érzelmi kimerülés, a cinizmus és a személyes hatékonyság csökkenésének mérése esetében. A kérdôív azonban a tételek hallgatókra szabott megfogalmazása miatt nem alkalmas az általános és középiskolás korosztálynál való használatra. 


\section{A diák kiégés kapcsolata más változókkal}

Az iskolások kiégésének összefüggéseit számos demográfiai és pszichológiai eredetú változóval vizsgálták. Nemi különbséget számos tanulmányban kimutattak, amelyek szerint a lányok alapvetôen magasabb pontszámokkal jellemezhetôk a kiégés kérdôíveken, mint a fiúk (Herrmann és mtsai, 2019; Kiuru és mtsai, 2008; Salmela-Aro és Tynkkynen, 2012). Ugyanakkor a kutatások arra is felhívják a figyelmet, hogy a nem és a kiégés közötti összefüggésre olyan mediáló tényezôk is kifejtik hatásukat, mint az önértékelés és a tanulmányi motiváció, amelyek tekintetében a meglévô nemi különbségek magyarázatot adhatnak a kiégés esetében megmutatkozó eltérésekre is (Herrmann és mtsai, 2019). Ugyanakkor longitudinális vizsgálattal azt is kimutatták, hogy a fiúk esetében gyorsabb ütemben erôsödnek meg a kiégés tünetei, mint a lányoknál (Salmela-Aro és Tynkkynen, 2012). A tanulmányi eredmény és a kiégés kapcsolatára vonatkozóan gyenge negatív együtt járásról számolnak be a kutatások, elsôsorban az érzelmi kimerülés és a cinizmus dimenziók mentén (Fiorilli és mtsai, 2017; Herrmann és mtsai, 2019). A tanulmányi eredmény mellett az iskolából való hiányzás gyakorisága is kapcsolatba hozható a kiégéssel, ugyanis az erôsebb tünetekrôl beszámoló diákok esetében magasabb a hiányzások száma is (Seibert és mtsai, 2017). Utóbbi eredmény kapcsolatba hozható az érzelemszabályozási stratégiákkal is, mert a kutatások szerint az érzelmek elfojtása közvetítôként van jelen a kiégés és a hiányzási arány kapcsolatában (Seibert és mtsai, 2017). A hiányzási arány valószínúleg nem közvetlenül kapcsolódik a kiégéshez, mert a két tényezô közötti összefüggést nem minden kutatás erôsíti meg, egyes tanulmányok nem szignifikáns együtt járásról számolnak be a kiégéssel összevetve (Fiorilli és mtsai, 2017).

A tanulmányi eredményekhez hasonlóan a diákok tanulás iránti motivációja is öszszefüggést mutat a kiégés tüneteinek megjelenésével. A kapcsolat iránya és erôssége azonban erôsen függ a motiváció típusától. A külsô, jutalmak és büntetések függvényében kialakuló motiváció gyenge pozitív kapcsolatot mutat a kiégéssel, míg az intrinzik motiváció esetében negatív együtt járás figyelhetô meg a két tényezô között. A legerôsebb pozitív kapcsolatot azonban a motivációhiány és a kiégés között találták (Chang, Lee, Byeon, Seong és Lee, 2016). Ez az eredmény hangsúlyozza a kiégés elméleti hátterének azon vetületét, amely szerint a teljesítménycsökkenés, inkompetenciaérzet és a felerôsödô cinizmus fontos tünete lehet a diákok körében megjelenố burnoutszindrómának is. Ezt erôsítik meg azok a kutatások is, amelyek a célorientációs elmélet (Dweck és Leggett, 1988; Elliot, McGregor és Gable, 1999) megközelítését használva hasonló összefüggéseket találtak a teljesítménycélok és a kiégés között. A kudarcok és rossz eredmények elkerülésére vonatkozó motiváció pozitív kapcsolatban áll a kiégéssel, míg a készségek fejlesztésére, elsajátítására vonatkozó célok negatív összefüggésben állnak a tünetekkel (Tuominen-Soini, Salmela-Aro és Niemivirta, 2012). Hasonló eredményrôl számolnak be azok a sportolók körében végzett vizsgálatok is, melyek a célorientáció és a kiégés kapcsolatát vizsgálták. A kiégés pozitívan kapcsolódik az elkerülô célokhoz, míg az elsajátító motivációval fordított összefüggést mutatnak a tünetek (Isoard-Gautheur, Trouilloud, Gustafsson és Guillet-Descas, 2016).

A pszichológiai jellegú tényezók esetében sokat vizsgált terület továbbá az önértékelés és a kiégés összefüggése. A kutatások szerint a kiégés tényezői negatív kapcsolatban 
állnak az önértékeléssel (Herrmann és mtsai, 2019; Luo, Wang, Zhang, Chen és Quan, 2016). Ezt az összefüggést az magyarázhatja, hogy a burnoutszindróma egyik tünete a teljesítménycsökkenés/alkalmatlanságérzés, ami az alacsonyabb tanulmányi eredmény és az átélt negatív érzések tükrében magyarázhatja a csökkent önértékelést.

\section{Az iskolai kötödés kapcsolata a kiégéssel}

A diák kiégés témakörben elengedhetetlen az iskolához való viszony vizsgálata is. Az iskolai kötôdés fogalmának leírása a szakirodalomban nem egységes. A fogalom megalkotója, Hirschi (1969) szerint az iskolai kötôdés két aspektusból tevôdik össze: az elsô az intézményhez való érzelmi viszonyulás, a másik pedig a személyekhez, elsôsorban a pedagógusokhoz való kötôdés. Jenkins (1997) emellett a kortársakkal való kapcsolatot és az iskolai értékek iránti elkötelezettséget is beépítette modelljébe. Moody és Bearman (1998) három dimenzióban foglalja össze az iskolához való viszonyt: pozitív érzelmi viszonyulás, iskolával való azonosulás és megfelelô minôségú kortárskapcsolatok. Ideális esetben a diák azonosulni tud az intézménnyel, a rendszer részének érzi magát, és kapcsolatokat alakít ki társaival és tanáraival egyaránt. Jóllehet a definíciók más-más tényezôt emelnek ki, de közös vonásuk, hogy a kötôdés legfontosabb eleme a pozitív érzelmi viszonyulás az iskola valamely vagy akár több aspektusához.

Az iskolához való kötôdés mértéke több tényezó együttes hatásától függ. Az iskolai kötôdéssel kapcsolatos kutatások mindegyike hangsúlyozza a tanár-diák és a kortárskapcsolatok fontosságát (Osterman, 2000; Samdal, Nutbeam, Wold és Kannas, 1998). Ezen túl az iskola nagysága is hatással van a kötôdésre, hiszen egy kisebb létszámú iskolában lehetôség van a közvetlenebb tanár-diák kapcsolat kiépítésére (Blum, McNeely és Rinehart, 2002). Az iskolához való kötődést növeli továbbá a szakkörökön, tanterven kívüli órákon való részvétel és az iskolai barátok száma (Blum és mtsai, 2002).

A diák az iskolában számos társadalmi és szociális tapasztalatot szerez, ezért az iskolához való viszonyulás minôségének hatása megjelenik a viselkedésben és a személyiségben is (Mészáros, 2004). Pozitív együtt járást mutattak ki az iskolához való kötôdés és a tanulmányi teljesítmény között (Bond és mtsai, 2007; Szabó és Virányi, 2011). Az iskolához kötôdô diákok magasabb önértékelésrôl és pozitívabb énképrôl számoltak be (Millings, Buck, Montgomery, Spears és Stallard, 2012; Szabó és Virányi, 2011). Kevésbé fegyelmezetlenek, tisztelik tanáraikat és társaikat; normakövetôk, a szabályokat betartják (Simons-Morton és mtsai, 1999). Nem jellemzô rájuk az iskolakerülés és a szerhasználat, csökken a tinédzserkori terhesség kockázata is (Blum és mtsai, 2002). Azonban az iskolában átélt negatív élmények, a magas szintú iskolai stressz felelôs lehet a gyenge mértékú kötôdésért (Katona és Szitó, 2000; Samdal és mtsai, 1998). Ezek alapján feltételezhetô, hogy az iskolai kötôdés és a diák kiégés között fordított irányú kapcsolat van.

\section{A vizsgálat célja és hipotézisei}

Kutatásunk fố célja az, hogy reflektáljon a diák kiégés jelenségének vizsgálatára középiskolai környezetben. A hazai szakirodalom áttekintése alapján úgy túnik, hogy 
a burnoutszindróma iskolások körében végzett feltárása még hiányzik, ami kiemeli annak szükségességét, hogy rendelkezzünk magyar nyelven elérhetô és jól használható kérdôívvel a probléma megközelítése érdekében. Ezért kutatásunk elsôdleges célja a Diák Kiégés Kérdôív (Salmela-Aro és mtsai, 2009, 2008) magyar nyelvú változatának tesztelése hazai mintán, ellenôrizve a kérdôív strukturális felépítését és megbízhatóságát. Emellett célunk megvizsgálni a kiégés kérdőíven elért pontszámok kapcsolatát más demográfiai és pszichológiai változókkal, amelyek a korábbi kutatások alapján releváns tényezôknek tûnnek a burnoutszindrómával kapcsolatban. Elsôként megvizsgáljuk, hogy a Diák Kiégés Kérdôív (Hietajärvi és mtsai, 2019; Luo és mtsai, 2016; Salmela-Aro és mtsai, 2009) általunk kialakított magyar adaptációja megfelelő pszichometriai tulajdonságokkal bír-e a skála szerkezetét és belsô megbízhatóságát tekintve. Amennyiben sikerül igazolni a kérdőív megbízhatóságát, úgy az alábbi hipotézisek vizsgálatát végezzük el, részben a kérdōív konvergens és divergens validitásának ellenôrzése, részben a kiégés jelenségének jobb megértése érdekében:

H1: A kiégéspontszám tekintetében a lányokra magasabb pontszám jellemzô, mint a fiúkra (Herrmann és mtsai, 2019; Salmela-Aro és Tynkkynen, 2012).

H2: A kiégéspontszám negatív kapcsolatban áll a tanulmányi eredménnyel (Herrmann és mtsai, 2019).

H3: A kiégéspontszám negatív együtt járást mutat az önértékeléssel (Herrmann és mtsai, 2019; Luo és mtsai, 2016).

H4: A kiégéspontszám negatív együtt járást mutat a közelítô célorientációval, míg pozitív kapcsolatban áll az elkerülố célokkal (Isoard-Gautheur és mtsai, 2016). A kiégésszindrómával való összevetéshez amiatt választottuk a célorientációs elméletet, mert a viszonyító motiváció társas jellege miatt illeszkedik a kiégés tüneteinek interperszonális jellegéhez, például a cinizmushoz és elidegenedéshez.

H5: A kiégéspontszám és az iskolai kötôdés negatív kapcsolatban áll egymással (Katona és Szitó, 2000; Samdal és mtsai, 1998).

\section{MÓDSZEREK}

\section{Minta és eljárás}

Az adatfelvétel során hozzáférési alapú mintavételt alkalmaztunk. A jelen elemzésbe bevont minta több, egymástól független adatfelvételbôl jött létre. Ez azt jelenti, hogy nem egy, hanem több intézményben zajlott az adatfelvétel. A kutatásban összesen két általános iskola és öt középiskola (mindegyik szakgimnázium) vett részt. Az iskolák a dél-alföldi régióban elhelyezkedô városi, állami fenntartású intézmények voltak. Az adatfelvételek 2018. október-december időszakban zajlottak. A felkért iskolák közül egy sem utasította vissza a megkeresést. A teljes mintába összesen 1075 diák tartozott (657 lány és 379 fiú, 39 válasz nélkül), akiknek átlagéletkora 15,3 év volt (szórás = 2,01 év). A minta 31,3\%-át általános iskola hetedik és nyolcadik osztályba járó diákok alkották (337 fô), míg a fennmaradó 68,7\% középiskolában tanult (738fő). A diákok minden esetben iskolai környezetben, osztályfőnöki órán, papíralapon töltötték ki a kérdőiveket. Az adatfelvételt megelôzoóen elôször a részt vevô oktatási intézmények vezetôi engedélyezték a vizsgálatot. Ezt követôen a szülôknek tájékoztatót küldtünk 
az adatfelvételrôl, és beleegyezésüket kértük gyermekük részvételéhez. A 14 évnél fiatalabb diákok esetében aktív, a 15-18 éves diákok esetében passzív beleegyezó nyilatkozatot használtunk. Szülôi beleegyezés nélkül a diákok nem vehettek volna részt az adatfelvételben, de ilyen eset nem történt a vizsgálatban. Ezt követôen a kitöltésben részt vevô diákok tájékoztatást kaptak a felvétel céljáról, majd szabadon dönthettek a kérdőív kitöltésérôl. A résztvevoók a kérdôív kitöltéséért semmiféle jutalmazásban nem részesültek. Az adatfelvételt az intézményekben dolgozó iskolapszichológusok koordinálták. A kérdőívek kitöltése osztályfőnöki óra keretei között történt, és maximum 25 percig tartott egy-egy osztályban. A kutatásban alkalmazott adatfelvételi módszert a Pszichológiai Kutatások Egyesült Etikai Bíráló Bizottsága előzetesen jóváhagyta (referenciaszám: 2017/122).

\section{Méröeszközök}

\section{Demográfiai adatok}

A kérdôívben a következô demográfiai adatok szerepeltek: nem, életkor, tanulmányi átlag. Utóbbi esetében a diákok önbevallással nyilatkoztak arról, hogy fôként milyen érdemjegyeket kaptak a legutóbbi félévi bizonyítványukban.

\section{Diák Kiégés Kérdôiv}

Az eredeti Diák Kiégés Kérdôív (School Burnout Inventory; SBI;) Salmela-Aro és munkatársai $(2009,2008)$ nevéhez fưzôdik. A kérdőív kilenc tételbôl álló, önkitöltéses mérôeszköz. A kitöltôk hatfokozatú Likert-skálán jelölhetik válaszaikat ( 1 = „Egyáltalán nem jellemzô rám”; 6 = „Teljesen jellemzô rám”). A kérdôív három alskálán különíti el a kiégés tüneteit: kimerülés, cinizmus és alkalmatlanságérzés.

A fordítás (Beaton, Bombardier, Guillemin és Ferraz, 2000) a kérdôív adaptációs leírása alapján készült, amely szerint az itemeket három személy fordította angolról magyarra, majd ezeket két szakértô (kétnyelvú személy) egységesítette. Ezen változatot két személy angolra fordította vissza az angol és magyar változat közötti eltérések kizárása érdekében. Ezeket a verziókat egy kétnyelvú szakember vetette össze. A végsô kérdôívbe az eredeti jelentéshez leginkább közel álló változat került bele.

\section{Rosenberg-féle Önértékelés Kérdôiv}

Az önértékelés viszonylag stabil pszichológiai jellemzô, amely szorosan összefonódik az egyén pszichés jóllétével, ezért gyakran áll a kutatások fókuszában (Sallay, Martos, Földvári, Szabó és Ittzés, 2014). Az eredetileg Rosenberg (1965) által létrehozott RSES-H skála az önértékelés konstruktumának megbízható mérôeszköze. A kérdôívnek több magyar változata is készült, ezek közül a Sallay és munkatársai (2014) által létrehozott 10 tételes verziót alkalmaztuk kutatásunkban. A mérôeszköz kiváló belsô megbízhatósággal és pszichometriai jellemzókkel bír, melyeket a jelenlegi adatokon is ellenóriztünk (Cronbach- $\alpha=0,845)$. A kitöltôk négyfokozatú Likert-skálán jelölhették válaszaikat ( 1 = „Egyáltalán nem értek egyet”; 4 = „Teljes mértékben egyetértek”). 


\section{Célorientációs Kérdôív}

A diákok teljesítménymotivációját a célorientációs elmélet (Dweck és Leggett, 1988; Elliot és mtsai, 1999) keretében vizsgáltuk. Az eredeti elmélet két dimenzió mentén különíti el a teljesítményhelyzetekben megjelenô motivációkat: elsajátítási célokat tûznek ki maguk elé azok, akiket készségeik fejlesztése motivál, azonban viszonyító célokkal rendelkeznek azok, akik a társas környezethez képest ítélik meg teljesítményüket. A másik dimenziót a közelítô és az elkerülô viselkedés jellemzi: a közelítô célok a jobb eredmények elérésére vonatkoznak, míg az elkerülô célok a kudarcok és sikertelenségek távolításához kapcsolódnak.

A kutatáshoz a Célorientációs Kérdôív magyar adaptációját (Pajor, 2013) használtuk. Az önkitöltéses kérdôív összesen 20 tételbôl áll, amelyek az eredeti négy helyett a magyar adaptációban összesen három alskálát alkotnak: viszonyító (Cronbach- $\alpha=0,875$ ), közelítô-elsajátító (Cronbach- $\alpha=0,797$ ) és elkerülô-elsajátító (Cronbach- $\alpha=0,838$ ) célorientációkat különböztet meg a mérôeszköz. A kérdőíven ötfokozatú Likert-skálán adnak választ a kitöltôk ( 1 = „Egyáltalán nem jellemző rám”; 5 = „Teljes mértékben jellemzô"), az alskálák jó belsố megbízhatósággal rendelkeznek.

\section{Iskolai Kötődés Kérdốv}

Az iskolai kötôdés vizsgálatára a Szabó és Virányi (2011) által kidolgozott, 20 tételbôl álló mérôeszközt alkalmaztuk. A mérôeszköz öt faktoron különíti el a kötôdés egyes aspektusait: az iskolához való általános viszonyulás, a társakhoz való viszony, a tanárokhoz való viszony, a tantárgyak iránti érdeklôdés és az iskolai környezethez való viszony. A kérdôíven a résztvevook négyfokú Likert-skálán fejezhetik ki, hogy az adott állítás mennyire jellemzô rájuk ( 1 = „Egyáltalán nem jellemzô”; 4 = „Teljes mértékben jellemzô"); a magasabb pontértékek erôsebb kötôdést jelentenek. Az elemzésben a teljes skála átlagpontszámával dolgoztunk (Cronbach- $\alpha=0,877)$.

Az adatokat SPSS for Windows 24.0 és Jamovi 0.6.9.6 (The Jamovi Project, 2019) statisztikai programcsomagokkal elemeztük.

\section{EREDMÉNYEK}

\section{A Diák Kiégés Kérdôiv magyar változatának strukturális elemzése}

Elsôként a Diák Kiégés Kérdôív faktorszerkezetét vizsgáltuk meg feltáró és megerôsítô faktorelemzés segítségével. Az elemzésekhez Fabrigar és munkatársai (1999) keresztvalidálásra vonatkozó eljárásának megfelelôen véletlenszerú besorolás alapján kettéválasztottuk a mintát, és a feltáró és megerôsítô faktorelemzést két külön almintán végeztük el. A módszer szerint az elóbbi elemzéssel kapott struktúra érvényessége megbízhatóbban értékelhető, ha egy másik, független mintán történik a struktúra megerôsítése, mert ezzel kiszürhetôk azok az esetek, amikor a minta sajátosságai torzítják a faktorstruktúra illeszkedési mutatóit. A minták jellemzőit az 1. táblázatban foglaltuk össze. 
1. táblázat. A feltáró és megerôsítô faktorelemzésekhez véletlenszerú besorolás alapján létrehozott alminták fó jellemzôi

\begin{tabular}{llcc}
\hline & & Minta 1 & Minta 2 \\
\hline Elemszám & & 538 & 537 \\
Nemek & Lány & 335 & 322 \\
& Fiú & 183 & 196 \\
Iskola típusa & Általános iskola & 156 & 181 \\
& Középiskola & 382 & 356 \\
Átlagéletkor & & 15,4 év & 15,4 év \\
\hline
\end{tabular}

Az elôzetes elemzések alapján az 1. alminta alkalmasnak bizonyult a feltáró faktorelemzésre. A Kaiser-Meyer-Olkin-mutató mind a kilenc tétel esetében megfelelô értéket mutatott $(\mathrm{KMO}=0,876)$, hasonlóan a Bartlett-féle teszthez $(\mathrm{p}<0,001)$. A feltáró faktorelemzés során párhuzamos elemzéssel (Horn, 1965) határoztuk meg a vizsgált faktorok számát, mert ez a módszer lehetôvé teszi az egynél kisebb sajátértékú faktorok kiválasztását is (Hayton, Allen \& Scarpello, 2004). Az elemzéshez maximum likelihood módszert használtunk Oblimin-rotációval, ami alapján a tételek két faktorba rendezôdtek (2. táblázat). Samuels (2016) irányelveinek megfelelốen egy tétel minimumtöltésének meg kellett haladnia a 0,3-es értéket ahhoz, hogy figyelembe vegyük, a faktorstruktúra kialakításához kereszttöltése pedig nem lehetett ennél magasabb egyszerre két faktoron. Az 1-es tétel az alacsony töltése miatt egyik faktorhoz sem sorolható. Ennek egyik lehetséges oka az lehet, hogy a tétel megítélésénél túlsúlyban vannak a szélsôségesen pozitív válaszok, tehát ez az item nem differenciál megfelelően.

Mivel az elemzés alapján kapott szerkezet eltért az eredeti háromfaktoros modelltôl, megismételtük az elemzést a faktorok számának elốzetes meghatározásával is (2. táblázat). Az egyes tétel ebben az esetben sem kapcsolódik jelentôs mértékben a faktorok egyikéhez sem, így a további elemzésekból kihagytuk.

A megmaradt 8 tételen megerôsítô faktorelemzést végeztünk a 2. almintán, összehasonlítva a két- és a háromfaktoros szerkezetet. A modell illeszkedésmutatóinak értékeléséhez Hu és Bentler (1999) irányelvként meghatározott határértékeit használtuk (3. táblázat). Habár mindkét modell esetében szignifikáns különbség mutatkozott az elméleti modellhez képest ( $\mathrm{p}<0,001$ ), ez a próba érzékeny az elemszámra, így a többi mutató alapján értékeltük a struktúrák illeszkedését. A kétfaktoros modell elfogadható, míg a háromfaktoros szerkezet jó illeszkedésmutatókkal rendelkezik. A háromfaktoros modellben a tételek az eredeti kérdőív szerkezetének megfelelốn rendezôdtek faktorokba: az elsô faktor a cinizmus alskálának, a második faktor az alkalmatlanságérzésnek, a harmadik pedig az érzelmi kimerülésnek felel meg.

A létrejövô faktorok belsố megbízhatóságát a teljes mintán ellenôriztük. A cinizmus esetében jó (Cronbach- $\alpha=0,864)$, míg az alkalmatlanságérzés $(\alpha=0,608)$ és az érzelmi kimerülés faktor esetében $(\alpha=0,618)$ a skálákhoz tartozó itemek alacsony, de az itemek száma miatt elfogadható értékeket kaptunk (Hinton, Brownlow, McMurray és Cozens, 2004). A teljes, nyolc tételból álló skála megbízhatósága szintén jónak bizonyult (Cronbach- $\alpha=0,827)$. 
2. táblázat. A Diák Kiégés Kérdôív feltáró faktorelemzésének eredménye az egyes itemek faktortöltésével

Tételek

2. Az iskolában nem ösztönöz semmi, és gyakran úgy érzem, legszívesebben abbahagynám.

5. Úgy érzem, hogy kezdem elveszíteni az érdeklốdésem az iskola iránt.

6. Gyakran gondolok arra, hogy az iskolai munkának van-e egyáltalán értelme.

3. Gyakran sikertelennek érzem magam az iskolai munkában.

8. Régebben úgy gondoltam, jobban fogok teljesíteni az iskolában, mint ahogy most.

4. Sokszor rosszul alszom az iskolai dolgok miatt.

7. Szabadidômben is sokat gondolkozom az iskolai dolgokon.

9. Az iskolai túlterheltség miatt vannak problémáim a baráti, családi kapcsolataimban is.

1. Úgy érzem, az iskola túlterhel. Megmagyarázott variancia:

\begin{tabular}{|c|c|c|c|c|}
\hline \multicolumn{2}{|c|}{ Párhuzamos elemzés } & \multicolumn{3}{|c|}{ Háromfaktoros modell } \\
\hline 1 & 2 & 1 & 2 & 3 \\
\hline 0,905 & & 0,819 & & \\
\hline 0,806 & & 0,852 & & \\
\hline 0,759 & & 0,772 & & \\
\hline 0,484 & 0,344 & & 0,988 & \\
\hline & 0,361 & & 0,312 & \\
\hline & 0,673 & & & 0,672 \\
\hline & 0,548 & & & 0,514 \\
\hline & 0,607 & & & 0,543 \\
\hline $29,1 \%$ & $17,5 \%$ & $25,0 \%$ & $13,8 \%$ & $13,6 \%$ \\
\hline
\end{tabular}

3. táblázat. A megerôsítô faktorelemzés illeszkedésmutatói a két-, illetve háromfaktoros szerkezet esetében

\begin{tabular}{lccc}
\hline & Kétfaktoros modell & Háromfaktoros modell & $\begin{array}{c}\text { Illeszkedésmutató } \\
\text { határértéke } \\
(\text { Hu és Bentler, 1999) }\end{array}$ \\
\hline$\chi^{2}$ & 85 & 60,3 & - \\
$\mathrm{p}$ & $<0,001$ & $<0,001$ & $>0,05$ \\
$\chi^{2} / \mathrm{df}$ & 5,0 & 3,54 & $<3$ jó \\
RMSEA & 0,0865 & 0,069 & $<5$ elfogadható \\
RMSEA 90\% CI & $0,0687<\mathrm{CI}<0,105$ & $0,057<\mathrm{CI}<0,0883$ & $<0,05$ \\
CFI & 0,958 & 0,973 & $>0,95$ \\
TLI & 0,930 & 0,956 & $>0,95$ \\
SRMR & 0,0457 & 0,0373 & $<0,09$ \\
\hline
\end{tabular}


Habár a feltáró faktorelemzés kétfaktoros struktúrát tárt fel, a megerôsítô faktorelemzés eredményei miatt az eredetivel megfelelô háromfaktoros szerkezet használata is elfogadhatónak tûnik. Mivel utóbbi illeszkedik a kiégés tüneteinek elméleti háttér alapján feltételezhetô struktúrájához, illetve a kérdôív eredeti szerkezetéhez, ezért a továbbiakban ennek a használata mellett döntöttünk, és a három alskála használatával végeztük az elemzéseket.

Ismételt méréses varianciaanalízissel összehasonlítottuk az egyes alskálák átlagpontszámait. Az eredmények szerint statisztikailag szignifikáns eltérés található az alskálák között $[\mathrm{F}(2 ; 2116)=93,5, \mathrm{p}<0,001]$. A Tukey-féle post-hoc teszt szerint az alskálák közötti összehasonlítás is statisztikailag jelentôs eltéréseket mutat $(p<0,001)$, eszerint a diákok az alkalmatlanságérzés esetében érték el a legmagasabb átlagpontszámot ( $\mathrm{M}$ $=3,47$ pont $)$, amelyet a cinizmus $(M=3,23$ pont $)$ és az érzelmi kimerülés $(M=2,87$ pont) követ (4. táblázat).

\section{A diák kiégés kapcsolata a demográfiai változókkal}

A különbözó demográfiai mutatók mentén megvizsgáltuk az összefüggéseket a Diák Kiégés Kérdőív alskálái esetében. Elsôként független mintás t-próbával hasonlítottuk össze az általános és középiskolás diákok pontszámait. A csoportok között a kiégés-átlagpontszám $(p=0,644)$, illetve az érzelmi kimerülés $(p=0,290)$ és az alkalmatlanságérzés $(\mathrm{p}=0,170)$ dimenziókban nem volt statisztikailag szignifikáns különbség. A cinizmus alskála esetében azonban az általános iskolás diákok szignifikánsan magasabb ( $\mathrm{M}=3,42$ pont) átlagértéket értek el, mint a középiskolás tanulók $[\mathrm{M}=3,14$ pont; $\mathrm{t}(1060)=2,794 ; \mathrm{p}=0,005]$.

Elsố hipotézisünkben feltételeztük, hogy a lányok esetében magasabb pontszámok jellemzőek, mint a fiúknál. A független mintás t-próbával végzett nemek közötti összehasonlítás azonban sem a teljes skála, sem pedig az alskálák esetében nem mutatott ki statisztikailag szignifikáns különbséget ( $>$ >0,05; lásd 4. táblázat). Az elsô hipotézisünkben feltételezett nemi különbségeket tehát nem igazolták az elemzések.

Második hipotézisünkben feltételeztük, hogy fordított irányú együtt járás található a kiégéspontszám és a tanulmányi eredmény között. A hipotézist Spearman-féle

4. táblázat. A Diák Kiégés Kérdôív alskáláinak leíró statisztikai mutatói, illetve a nemek közötti különbséget feltáró független mintás t-próba eredménye

\begin{tabular}{|c|c|c|c|c|c|c|c|c|c|}
\hline & $\mathrm{N}$ & $\begin{array}{l}\text { Cron- } \\
\text { bach- } \alpha\end{array}$ & Átlag & Szórás & Csoport & $\mathrm{N}$ & Átlag & Szórás & T-próba \\
\hline \multirow{2}{*}{$\begin{array}{l}\text { Diák kiégés } \\
\text { (teljes skála) }\end{array}$} & \multirow{2}{*}{1059} & \multirow{2}{*}{0,827} & \multirow{2}{*}{3,16} & \multirow{2}{*}{1,15} & Fiú & 375 & 3,12 & 1,11 & \multirow{2}{*}{$\mathrm{p}=0,345$} \\
\hline & & & & & Lány & 646 & 3,19 & 1,19 & \\
\hline \multirow{2}{*}{$\begin{array}{l}\text { Érzelmi } \\
\text { kimerülés }\end{array}$} & \multirow{2}{*}{1064} & \multirow{2}{*}{0,618} & \multirow{2}{*}{2,87} & \multirow{2}{*}{1,3} & Fiú & 377 & 2,85 & 1,26 & \multirow{2}{*}{$\mathrm{p}=0,593$} \\
\hline & & & & & Lány & 649 & 2,90 & 1,32 & \\
\hline \multirow{2}{*}{ Cinizmus } & \multirow{2}{*}{1062} & \multirow{2}{*}{0,864} & \multirow{2}{*}{3,23} & \multirow{2}{*}{1,55} & Fiú & 375 & 3,15 & 1,44 & \multirow{2}{*}{$\mathrm{p}=0,263$} \\
\hline & & & & & Lány & 649 & 3,26 & 1,61 & \\
\hline \multirow{2}{*}{$\begin{array}{l}\text { Alkalmatlanság- } \\
\text { érzés }\end{array}$} & \multirow{2}{*}{1064} & \multirow{2}{*}{0,608} & \multirow{2}{*}{3,47} & \multirow{2}{*}{1,4} & Fiú & 377 & 3,45 & 1,39 & \multirow{2}{*}{$p=0,704$} \\
\hline & & & & & Lány & 649 & 3,49 & 1,42 & \\
\hline
\end{tabular}


rangkorrelációval ellenôriztük. Az eredmények szerint a Diák Kiégés Kérdôív átlagpontszáma statisztikailag jelentôs, gyenge negatív együtt járást mutat a tanulmányi eredménnyel $[\mathrm{r}(1062)=-0,240 ; \mathrm{p}<0,001]$. Az alskálák közül az érzelmi kimerülés esetében nem található statisztikailag jelentôs összefüggés a tanulmányi eredménnyel $(\mathrm{p}>0,05)$, míg a cinizmus $[\mathrm{r}(1062)=-0,215 ; \mathrm{p}<0,05]$ és az alkalmatlanságérzés $[\mathrm{r}(1062)=-0,322 ; \mathrm{p}<0,001]$ esetén a várt irányú szignifikáns, de viszonylag gyenge együtt járást találtuk.

\section{Konvergens és divergens validitás}

A konvergens és a divergens validitás tesztelése érdekében megvizsgáltuk a Diák Kiégés Kérdőív pontszámainak összefüggéseit a korábban bemutatott kérdőíveken kapott értékekkel.

Harmadik hipotézisünkben feltételeztük, hogy a kiégés negatív együtt járást mutat az önértékeléssel. A változók közötti összefüggéseket Pearson-féle korrelációelemzéssel tártuk fel. Az eredmények alapján statisztikailag szignifikáns, gyenge negatív korreláció van a diák kiégés átlagpontszáma és az önértékelés között [r(140) = -0,290; $\mathrm{p}<0,05]$. Az eredmények hasonlóak mindhárom alskála esetében: az érzelmi kimerülés $[\mathrm{r}(140)=-0,198 ; \mathrm{p}<0,05]$, a cinizmus $[\mathrm{r}(140)=-0,244 ; \mathrm{p}<0,05]$ és az alkalmatlanságérzés $[\mathrm{r}(140)=-0,273 ; \mathrm{p}<0,05]$ is negatív összefüggést mutat az önértékeléssel, habár az együtt járás csak gyenge mértékú.

Negyedik hipotézisünkben negatív együtt járást feltételeztünk a célorientáció dimenziói és a kiégés kérdőív átlagpontszáma között. A közelítô célorientáció esetében gyenge negatív együtt járást találtunk a kiégés-átlagpontszámmal $[\mathrm{r}(721)=-0,151$; p $<0,05]$, hasonlóan az alkalmatlanságérzés $[\mathrm{r}(721)=-0,137 ; \mathrm{p}>0,05]$ és a cinizmus $[\mathrm{r}(721)=-0,314 ; \mathrm{p}<0,05]$ alskálák esetében. Az érzelmi kimerülés alskála azonban a hipotézisünkkel ellentétben nagyon gyenge, de szignifikáns pozitív együtt járást [r(721) = 0,123; $\mathrm{p}<0,05]$ mutatott a közelítô-elsajátító célorientációval. Az elkerülő-elsajátító célorientáció esetében az előfeltevésnek megfelelően pozitív összefüggést találtunk a diákkiégés-pontszámmal $[\mathrm{r}(646)=0,207 ; \mathrm{p}<0,05]$. Az alskálák közül a cinizmus nem

5. táblázat. A diákkiégés-átlagpontszám és alskáláinak korrelációs együtthatói más változókkal

\begin{tabular}{lcccc}
\hline & Diák kiégés & $\begin{array}{c}\text { Érzelmi } \\
\text { kimerülés }\end{array}$ & Cinizmus & $\begin{array}{c}\text { Alkalmatlanság- } \\
\text { érzés }\end{array}$ \\
\hline Tanulmányi eredmény & $-0,240^{* *}$ & $\mathrm{n} . \mathrm{sz}$. & $-0,215^{* *}$ & $-0,322^{* *}$ \\
Életkor & $0,109^{* *}$ & $0,089^{*}$ & 0,1 & $\mathrm{n} . \mathrm{sz}$. \\
Önértékelés & $-0,290^{* *}$ & $-0,198^{* *}$ & $-0,244^{* *}$ & $-0,273^{* *}$ \\
Elkerüló célorientáció & $0,207^{* *}$ & $0,342^{* *}$ & $\mathrm{n} . \mathrm{sz}$. & $0,186^{* *}$ \\
Közelítô-elsajátító & $-0,151^{* *}$ & $0,123^{* *}$ & $-0,314^{* *}$ & $-0,137^{* *}$ \\
célorientáció & $\mathrm{n} . \mathrm{sz}$. & $0,226^{* *}$ & $-0,105^{*}$ & $\mathrm{n} . \mathrm{sz}$. \\
Viszonyító célorientáció & $-0,574^{* *}$ & $-0,205^{* *}$ & $-0,400^{* *}$ & $-0,698^{* *}$ \\
Iskolai kötốdés & & & & \\
\hline
\end{tabular}

Megjegyzés: $* \mathrm{p}<0,05, * * \mathrm{p}<0,001$ 
mutatott statisztikailag jelentôs együtt járást az elkerülő célokkal ( $\mathrm{p}>0,05)$, míg az érzelmi kimerülés $[\mathrm{r}(646)=0,342 ; \mathrm{p}<0,05]$ és az alkalmatlanságérzés $[\mathrm{r}(646)=0,186$; $\mathrm{p}<0,05$ ] esetében gyenge, de a hipotézisnek megfelelő irányú kapcsolatot tártak fel az elemzések.

Ötödik hipotézisünkben az iskolai kötôdés és a diákkiégés-átlagpontszám negatív együtt járását feltételeztük. A Pearson-féle korrelációelemzés alapján a kiégéspontszám és a kötôdés között szignifikáns negatív összefüggést találtunk $[\mathrm{r}(360)=-0,574$; $\mathrm{p}<0,05]$. Az alskálák közül az érzelmi kimerülés áll a leggyengébb kapcsolatban az iskolai kötôdéssel $[\mathrm{r}(360)=-0,205 ; \mathrm{p}<0,05]$, míg az alkalmatlanságérzés $[\mathrm{r}(360)=-0,400$; $\mathrm{p}<0,05]$ és a cinizmus $[\mathrm{r}(360)=-0,698 ; \mathrm{p}<0,05]$ erôsebb összefüggést mutat.

\section{Inkrementális validitás: regresszióelemzés}

Hierarchikus regresszióelemzéssel vizsgáltuk meg, hogy a kiégés kérdőív más prediktorokkal együtt vizsgálva képes-e megmagyarázni valamely más pszichológiai változó varianciájának egy részét. Függő változóként az iskolai kötôdést választottuk, majd elsô lépésként a célorientáció három típusát, második lépésként pedig a diák kiégés átlagpontszámát vettük be a modellbe. A teljes modell esetében a magyarázott variancia 50,3\%. Az eredmények szerint a kiégés, a többi jellemzôtôl függetlenül és azok beszámítása mellett is szignifikáns magyarázó erôvel bír az iskolai kötôdésre nézve $[\mathrm{F}(4 ; 355)=90, p<0,001]$. A modell részletei a 6 . táblázatban vannak feltüntetve.

\section{DISZKUSSZIÓ}

Kutatásunk célja a Diák Kiégés Kérdôív (Salmela-Aro és mtsai, 2009, 2008) magyar nyelvú változatának strukturális feltárása, megbízhatóságának vizsgálata volt hazai mintán. Emellett a diák kiégéssel kapcsolatban kapott eredményeket összevetettük az önértékeléssel, a célorientációs típusokkal és az iskolai kötôdéssel, hogy ellenôrizzük a skála külsố validitását.

A kérdôív hazai adaptációjának faktorszerkezete a feltáró faktorelemzés alapján nem tükrözte a korábbi háromfaktoros struktúrát. Az eredmények szerint két fớ fak-

6. táblázat. A hierarchikus regresszióelemzés eredménye. A modell függố változója az iskolai kötôdés volt.

\begin{tabular}{lccc}
\hline & $\beta$ & $\Delta \mathrm{R}^{2}$ & $\mathrm{~F}$ \\
\hline 1. lépés & & 0,273 & $44,5^{* *}$ \\
Közelítô-elsajátító célorientáció & $0,594^{* *}$ & & \\
Viszonyító célorientáció & $-0,047$ & & \\
Elkerülố célorientáció & $-0,109$ & & \\
\hline 2. lépés & & 0,231 & $90^{* *}$ \\
Diák kiégés & $-0,53^{* *}$ & & \\
\hline
\end{tabular}

Megjegyzés: **p $<0,001$ 
torba rendezôdnek a tételek, egy item kiesésével. Ebben a struktúrában az eredetileg az érzelmi kimerülés- és az alkalmatlanságérzés faktorokhoz tartozó tételek mutattak átfedést. A feltáró elemzést megismételtük három faktor előzetes beállításával. Ennek eredményeként az eljárás során az eredetivel teljesen megegyezô struktúrát mutattak a tételek, egy item kiesésével. A megerôsítő faktorelemzéssel összehasonlítva a két- és a háromfaktoros struktúra illeszkedésmutatóit, arra jutottunk, hogy az eredetivel megegyezô felépítésû, háromfaktoros struktúra minden mutató esetében jobb illeszkedést mutat, mint a kétfaktoros elrendezésnél, emiatt ennek az alkalmazása mellett döntöttünk. A további elemzések rámutattak, hogy az alskálák eredményei között szignifikáns különbségek vannak, ami megerôsíti, hogy az általunk kialakított mérôeszköz képes differenciálni a kiégés egyes tünetei között, így segítheti a problémás területek azonosítását. Emellett az eredmények alapján feltételezhetô, hogy az alkalmatlanságérzés lehet a leggyakoribb kiégéssel kapcsolatos tünet, amely összefügghet az önértékelési problémák és szorongásos zavarok kialakulásával. Ezek a tünetek ugyanis magas prevalenciát mutatnak elsôsorban serdülôkorban (Connolly, Suarez és Sylvester, 2011).

A kedvezố szerkezeti mutatók ellenére azonban a kérdôív alskálái nem tekinthetốk teljesen megbízhatónak. A teljes skála, illetve a cinizmus alskála belsô reliabilitása jónak mutatkozott, ugyanakkor a kérdôívvel kapcsolatos limitációk közé tartoznak az alkalmatlanságérzés és az érzelmi kimerülés alskálák alacsony, de még elfogadható Cronbach-alfa-mutatói. Az alkalmatlanságérzés alskála esetében már az eredeti vizsgálat (Salmela-Aro és mtsai, 2008) is alacsony belsô megbízhatóságot tárt fel, és erre az eredményre jutott a kérdôív német változatát elemzô kutatás is (Herrmann és mtsai, 2019). A kérdôívvel kapcsolatos korábbi tapasztalatok megerôsítik a saját adataink által is feltárt bizonytalanságot az alskálák megfelelő múködésével kapcsolatban. Ezért a kérdôív egydimenziós mérôeszközként való használatát javasoljuk, az egyes alskálák megkülönböztetése nélkül, elkerülve a bizonytalanságokból fakadó mérési hibákat. Egydimenziós mérôeszközként azonban a feltáró faktorelemzés eredményei alapján kihagyott tétel törlésére sincs feltétlenül szükség. Eredményeink megerôsítik, hogy az eredeti, kilenctételes kérdôív egyetlen skálaként alkalmazva némileg jobb belsô megbízhatósággal jellemezhetô (Cronbach-alfa $=0,831$ ), mint a nyolctételes változat (Cronbach-alfa $=0,827)$.

Az általunk vizsgált mintát a közepesnél kissé erôsebb összesített kiégéspontszám jellemzi. A korábbi kutatási eredményekkel ellentétben nem találtunk jelentôs különbséget a fiúk és a lányok átlagpontszámai között (Herrmann és mtsai, 2019; Salmela-Aro és Tynkkynen, 2012). Az általános és középiskolás diákok eredményeinek összehasonlítása esetén csak a cinizmus alskála esetében találtunk jelentôs különbséget az átlagpontszámok között. Mindezt indokolhatja, hogy a középiskolás diákok - elsôsorban a végzéshez közelebb álló tanulók - a szakmai vizsgák és az érettségi közeledtével jobban érzékelik a tanulás hasznosságát, még ha ez nem is belsô, hanem külsô motivációként jelenik meg az esetükben.

Az eredmények felhasználásával kapcsolatban fontos kérdés, hogy alkalmasak-e a kapott adatok arra, hogy a pontszámok alapján meghatározható legyen a magas kiégéssel jellemezhetô övezet. Két fontos tényezô miatt ütközik korlátokba az erre vonatkozó törekvésünk. Egyrészt az elemzett minta nem tekinthetó reprezentatívnak, másrészt az adatfelvétel során nem használtunk olyan teszteket, amelyek célzottan a 
diákok pszichológiai állapotát tárták volna fel. A Diák Kiégés Kérdőív késôbbi diagnosztikai jellegú használatához mindenképpen további vizsgálatok szükségesek, hogy egy szélesebb mintavétellel feltárható legyen a pontszámok kapcsolata az olyan problémákkal, mint az észlelt stressz, a szorongás vagy a depresszió.

Ugyanakkor a kiégés elterjedtségével kapcsolatban tájékoztató lehet a kapott adatok értékelése a korábbi hasonló felmérések és kutatási eredmények tükrében. Az általános iskolás diákok között az átlagnál legalább egy szórásnyi értékkel nagyobb pontszámot a diákok 16,3\%-a ért el, míg a középiskolások között ugyanez az arány 16,1\%. Ebból arra következtethetünk, hogy a kiégés súlyos tünetei körülbelül a diákok hatodát érintik. Korábbi kutatások Finnországban 10\%-ra becsülték ugyanezt az értéket (Salmela-Aro és mtsai, 2008), egy késôbbi felmérés pedig a diákok 14\%-ánál állapított meg súlyos kiégést, a tanulók további 14\%-át pedig magas cinizmussal és alacsony elkötelezôdéssel jellemezhetô csoportként írta le. Középiskolás mintákon (négyfokú skálát használva) 1,81 és 1,94 közötti átlagpontszámokról számoltak be a kutatók a Diák Kiégés Kérdôívet használva (Salmela és mtsai, 2008), amihez képest a saját adatfelvételünkön kapott 3,14-es átlag magasnak mondható annak figyelembevételével is, hogy esetünkben hatfokú skálán válaszoltak a kitöltôk. Más vizsgálatok ötfokozatú skálát használva 2,46-os átlagértéket állapítottak meg középiskolás mintán, ami szintén alacsonyabbnak tekinthetô a magyar mintán kapott értékeknél (Sorkkila, Aunola és Ryba, 2017).

A diákok tanulmányi eredményessége a korábbi kutatási eredményekkel összhangban (Herrmann és mtsai, 2019) enyhe negatív együtt járást mutat a kiégéssel. A kapcsolat hátterében megjelenhet az iskolához és a tanulmányokhoz fúzôdô kiábrándult és cinikus viszony, ami a kiégés egyik faktora, de magyarázhatja a tanulás iránti motiváció csökkenése is. A kiégés az alacsonyabb elkötelezôdésen, illetve a kevésbé hatékony tanulási módszerek alkalmazásán keresztül hathat negatívan a tanulmányi eredményességre. Ugyanakkor megjelenhet az ellentétes irányú folyamat is, azaz, hogy a kiégés kialakulását a rossz érdemjegyekkel járó tanulmányi sikertelenség és az ebbôl fakadó csalódottság, frusztráció tartós stressze idézi elô. Ez utóbbi feltételezést támasztja alá, hogy a tanulmányi eredmény a legerôsebb együtt járást az alkalmatlanságérzés alskálával mutatta, amely kiemeli a negatív visszajelzések és kudarcok szerepét az iskolával kapcsolatos kiégés kialakulásában.

A mérôeszköz külsố validitását alátámasztották a teszteléséhez használt pszichológiai tényezókkel összefüggésben kimutatott gyenge, de szignifikáns és a várt irányba mutató együtt járások. Figyelemre méltó, hogy az önértékelés a legerôsebb negatív kapcsolatban az alkalmatlanságérzés alskála értékével volt, ami utal a konstruktumok jelentésbeli hasonlóságára. Ez az összefüggés - a tanulmányi eredményességhez hasonlóan - magyarázható a csökkent lelkesedésból következô alacsonyabb teljesítmény, és az ezzel együtt járó kudarcok gyakoribb átélésével. Az önértékelés és a kiégés értékei közötti gyenge kapcsolatra magyarázatot adhat, hogy a motiválatlanabb vagy erôsebb kiégést mutató diákok énképük védelme érdekében kisebb jelentôséget tulajdonítanak az iskolai eredményeknek, mint egyéb tényezôknek. Így a gyengébb teljesítmény feltételezhetốen nem jár együtt olyan erôsen a kiégéssel az esetükben, mint azoknál a diákoknál, akik motiváltak ugyan, de leterheltségüknél, kimerültségüknél fogva nem képesek saját és környezetük elvárásainak megfelelô szinten teljesíteni. Ennek a fel- 
tételezésnek a helyességét látszik alátámasztani, hogy az elkerülô és közelítô elsajátítási motiváció egyaránt pozitív korrelációs kapcsolatban állt a kiégéssel. Elképzelhetô, hogy a magas motivációjú diákokat, akár közelítô, akár elkerülő elsajátítási motivációval rendelkeznek, akadályozza céljaik elérésében a leterheltségük. Így érthetô, hogy a fejlôdés iránt elkötelezett és a jó eredmények elérésére törekvô diákok körében elsôsorban az érzelmi kimerülés tünete jelenik meg.

Ugyanakkor az is lehetséges, hogy a motiváltabb diákokra fokozottabban hathatnak az iskolában átélt negatív érzelmek is. Mivel fontosabb számukra az iskolai teljesítmény, vélhetôen több stresszt is jelent számukra vágyott céljuk elérése, ami fokozott érzelmi kimerülést is eredményezhet.

A célorientációval kapcsolatban kapott további összefüggések szintén gyenge, de a hipotézisekkel megegyezô kapcsolatot mutattak ki a diák kiégéssel. Eszerint a közelítô-elsajátító motiváció negatív, míg az elkerülô motiváció pozitív kapcsolatban áll a kiégéssel. Ezek a kapcsolatok magyarázhatók a kiégéssel együtt járó alacsonyabb elkötelezôdéssel, illetve magasabb kimerüléssel, ami miatt a diákok alacsonyabb célokat tûznek ki maguk elé. A legerôsebb, negatív irányú összefüggést a vártnak megfelelôen az iskolai kötôdés és a diákok kiégése között találtuk. Ez az összefüggés rámutat arra, hogy az iskolával, illetve a pedagógusokkal és a diáktársakkal kapcsolatban átélt negatív élmények és érzések hosszú távon túlterhelik a tanulókat érzelmileg, gyengítve ezáltal az elkötelezôdésüket az intézmény és a közösség iránt. Vizsgálatunk eredménye szerint a kiégés egyes elemei önmagukban és a többi tényezôvel együttesen is jelentôs bejósló erôvel bírnak az iskolai kötôdés alakulására. Utóbbi a kutatási eredmények szerint egyértelmúen befolyásolja a tanulmányi elômenetelt, valamint az iskolai szocializáció eredményességét is (vö. Simons-Morton és mtsai, 1999).

\section{Limitációk és továbbfejlesztési lehetôségek}

A kutatás limitációi közé tartozik, hogy nem állt módunkban a vizsgálatot életkorra, nemre, iskolatípusra reprezentatív mintán lefolytatni. Így, bár viszonylag nagy elemszámmal dolgoztunk, a teljes korosztályra nem vonhatunk le következtetéseket. Az eredmények általánosíthatóságának további korlátját az érzelmi kimerülés és az alkalmatlanságérzés alskálák alacsony belsố megbízhatósága jelenti. Még akkor is, ha ezt részben indokolhatja, hogy két-, illetve háromtételes alskálák esetében alacsonyabb az elvárható Cronbach-alfa-érték. Mindemellett a vizsgálat során nem ellenôriztük a skála idôbeli stabilitását, amely lehetséges továbbfejlesztési irányt jelent egy jövôbeni kutatás során.

\section{Következtetések}

Összességében a Diák Kiégés Kérdôív belsô szerkezetére vonatkozó eredmények, illetve a mérôeszköz más változókkal való kapcsolata megerôsíti azt a feltételezésünket, hogy a kérdôív jól használható eszköz lehet a jövooben iskolapszichológiai és neveléstudományi jellegú kutatásokban. Az alskálák között talált jelentôs különbségek utalnak 
arra, hogy a kiégés különbözô tüneteinek felmérésére és elkülönítésére is alkalmas a mérôeszköz. Emellett az alskálák és a vizsgálatba bevont pszichológiai változók közötti kapcsolatok megerôsítették, hogy a kiégés mérésére kidolgozott skála a feltárni kívánt konstruktumot méri. Mindezek alapján úgy ítéljük meg, hogy a Salmela-Aro és munkatársai (2008) által kifejlesztett Diák Kiégés Kérdőív magyar változata a kutatás mellett alkalmas eszköz lehet az általános és középiskolás korosztály kiégésének szúrô és problémafeltáró vizsgálatára, valamint prevenciós program megalapozását célzó mérésre is.

\section{IRODALOM}

Amerikai Pszichológiai Társaság (2014). Stress in America: Are teens adopting adults'stress habits? Letöltve: 2019. 06. 16. http://www.apa.org/news/press/releases/stress/2013/stress-report. pdf

Beaton, D. E., Bombardier, C., Guillemin, F., \& Ferraz, M. B. (2000). Guidelines for the process of cross-cultural adaptation of self-report measures. Spine, 25(24), 3186-3191.

Blum, R. W., McNeely, C., \& Rinehart, P. M. (2002). Improving the odds: The untapped power of schools to improve the health of teens. Elôadás Minneapolisban. Letöltve: 2019. 06. 16. https:// www.casciac.org/pdfs/ImprovingtheOdds.pdf

Bond, L., Butler, H., Thomas, L., Carlin, J., Glover, S., Bowes, G., \& Patton, G. (2007). Social and School Connectedness in Early Secondary School as Predictors of Late Teenage Substance Use, Mental Health, and Academic Outcomes. Journal of Adolescent Health, 40(4), 357. e9-357.e18. DOI: https://doi.org/10.1016/j.jadohealth.2006.10.013

Caroli, M. E. D., \& Sagone, E. (2012). Professional Self Representation and Risk of Burnout in School Teachers. Procedia - Social and Behavioral Sciences, 46, 5509-5515. DOI: https://doi. org/10.1016/j.sbspro.2012.06.466

Chang, E., Lee, A., Byeon, E., Seong, H., \& Lee, S. M. (2016). The mediating effect of motivational types in the relationship between perfectionism and academic burnout. Personality and Individual Differences, 89, 202-210. DOI: https://doi.org/10.1016/j.paid.2015.10.010

Connolly, S. D., Suarez, L., \& Sylvester, C. (2011). Assessment and Treatment of Anxiety Disorders in Children and Adolescents. Current Psychiatry Reports, 13(2), 99-110. DOI: https:// doi.org/10.1007/s11920-010-0173-z.

Dweck, C. S., \& Leggett, E. L. (1988). A social-cognitive approach to motivation and personality. Psychological Review, 95(2), 256-273. DOI: https://doi.org/10.1037/0033-295X.95.2.256

Elliot, A. J., McGregor, H. A., \& Gable, S. (1999). Achievement goals, study strategies, and exam performance: A mediational analysis. Journal of Educational Psychology, 91(3), 549-563. DOI: https://doi.org/10.1037/0022-0663.91.3.549

Fabrigar, L. R., Wegener, D. T., MacCallum, R. C., \& Strahan, E. J. (1999). Evaluating the use of exploratory factor analysis in psychological research. Psychological Methods, 4(3), 272-299. DOI: https://doi.org/10.1037/1082-989X.4.3.272

Fiorilli, C., De Stasio, S., Di Chiacchio, C., Pepe, A., \& Salmela-Aro, K. (2017). School burnout, depressive symptoms and engagement: Their combined effect on student achievement. International Journal of Educational Research, 84, 1-12. DOI: https://doi.org/10.1016/j. ijer.2017.04.001

Freudenberger, H. J. (1974). Staff Burn-Out. Journal of Social Issues, 30(1), 159-165. DOI: https://doi.org/10.1111/j.1540-4560.1974.tb00706.x 
Hayton, J. C., Allen, D. G., \& Scarpello, V. (2004). Factor Retention Decisions in Exploratory Factor Analysis: a Tutorial on Parallel Analysis. Organizational Research Methods, 7(2), 191-205. DOI: https://doi.org/10.1177/1094428104263675

Hazag, A., Major, J., \& Ádám, S. (2010). Assessment of burnout among students. Validation of the Hungarian version of the Maslach Burnout Inventory-Student Version (MBI-SS). Mentálhigiéné és Pszichoszomatika, 11(2), 151-168. DOI: https://doi.org/10.1556/Mental.11.2010.2.4

Herrmann, J., Koeppen, K., \& Kessels, U. (2019). Do girls take school too seriously? Investigating gender differences in school burnout from a self-worth perspective. Learning and Individual Differences, 69, 150-161. DOI: https://doi.org/10.1016/j.lindif.2018.11.011

Hietajärvi, L., Salmela-Aro, K., Tuominen, H., Hakkarainen, K., \& Lonka, K. (2019). Beyond screen time: Multidimensionality of socio-digital participation and relations to academic well-being in three educational phases. Computers in Human Behavior, 93, 13-24. DOI: https://doi.org/10.1016/j.chb.2018.11.049

Hinton, P. H., Brownlow, C., McMurray, I., \& Cozens, B. (2004). SPSS Explained. New York: Routledge.

Hirschi, T. (1969). Causes of Delinquency. Berkeley, CA: University of California Press.

Horn, J. L. (1965). A rationale and test for the number of factors in factor analysis. Psychometri$k a, 32,179-185$.

Hu, L., \& Bentler, P. M. (1999). Cutoff criteria for fit indexes in covariance structure analysis: Conventional criteria versus new alternatives. Structural Equation Modeling: A Multidisciplinary Journal, 6(1), 1-55. DOI: https://doi.org/10.1080/10705519909540118

Inchley, J., Currie, D., Young, T., Samdal, O., Torsheim, T., Augustson, L., et al. (2016). Growing up unequal: Gender and socioeconomic differences in young people's health and well-being. Health Behaviour in School-aged Children (HBSC) study: International report from the 2013/2014 survey. (Health Policy for Children and Adolescents, No. 7). Letöltve: 2019. 06. 16. http://www.euro. who.int/en/publications/abstracts/growing-up-unequal.-hbsc-2016-study-20132014-survey

Isoard-Gautheur, S., Trouilloud, D., Gustafsson, H., \& Guillet-Descas, E. (2016). Associations between the perceived quality of the coach-athlete relationship and athlete burnout: An examination of the mediating role of achievement goals. Psychology of Sport and Exercise, 22, 210-217. DOI: https://doi.org/10.1016/j.psychsport.2015.08.003

Jenkins, P. H. (1997). School Delinquency and the School Social Bond. Journal of Research in Crime and Delinquency, 34(3), 337-367. DOI: https://doi.org/10.1177/0022427897034003003

Katona, N., \& Szitó, I. (2000). Student stress in adolescence. Curriculum and Teaching, 15(2), $49-60$.

Kiuru, N., Aunola, K., Nurmi, J.-E., Leskinen, E., \& Salmela-Aro, K. (2008). Peer Group Influence and Selection in Adolescents' School Burnout: A Longitudinal Study. Merrill-Palmer Quarterly, 54(1), 23-55. DOI: https://doi.org/10.1353/mpq.2008.0008

Luo, Y., Wang, Z., Zhang, H., Chen, A., \& Quan, S. (2016). The effect of perfectionism on school burnout among adolescence: The mediator of self-esteem and coping style. Personality and Individual Differences, 88, 202-208. DOI: https://doi.org/10.1016/j.paid.2015.08.056

Martonné, T. M., \& N. Kollár, K. (2001). A tanulók életmódjának kérdốives vizsgálata. Budapest: Animula.

Maslach, C. (1982). Burnout: The cost of caring. New York: Prentice-Hall.

Maslach, C., \& Jackson, S. E. (1986). Maslach burnout inventory manual. Palo Alto, CA: Consulting Psychologists Press.

Maslach, C., \& Goldberg, J. (1998). Prevention of burnout: New perspectives. Applied and Preventive Psychology, 7(1), 63-74. DOI: https://doi.org/10.1016/S0962-1849(98)80022-X

Mészáros, A. (2004). Az iskola szociálpszichológiai jelenségvilága. Budapest: ELTE Eötvös. 
Millings, A., Buck, R., Montgomery, A., Spears, M., \& Stallard, P. (2012). School connectedness, peer attachment, and self-esteem as predictors of adolescent depression. Journal of Adolescence, 35(4), 1061-1067. DOI: https://doi.org/10.1016/j.adolescence.2012.02.015

Moody, J., \& Bearman, P. S. (1998). Shaping school climate: Shool context adolescent social networks, and attachmnet to school. Unpublished manuscript.

Näätänen, P., Aro, A., Matthiesen, S., \& Salmela-Aro, K. (2003). Bergen Burnout Indicator 15. Helsinki: Edita.

Osterman, K. F. (2000). Students' Need for Belonging in the School Community. Review of Educational Research, 70(3), 323-367. DOI: https://doi.org/10.3102/00346543070003323

Pajor, G. (2013). Serdülók teljesítménymotivációja a célorientációs elmélet tükrében. PhD-disszertáció. Előadás - ELTE Pszichológia Doktori Iskola. Letöltve: 2019. 06. 16. http://pszichologia.phd. elte.hu/vedesek/PAJOR_GABRIELLA_disszertacio.pdf

Purvanova, R. K., \& Muros, J. P. (2010). Gender differences in burnout: A meta-analysis. Journal of Vocational Behavior, 77(2), 168-185. DOI: https://doi.org/10.1016/j.jvb.2010.04.006

Räisänen, M., Postareff, L., Mattsson, M., \& Lindblom-Ylänne, S. (2018). Study-related exhaustion: First-year students' use of self-regulation of learning and peer learning and perceived value of peer support. Active Learning in Higher Education. DOI: https://doi. org/10.1177/1469787418798517

Rosenberg, M. (1965). Society and the Adolescent Self-Image. Princeton, N. J.: Princeton University Press.

Sallay, V., Martos, T., Földvári, M., Szabó, T., \& Ittzés, A. (2014). Hungarian version of the Rosenberg Self-esteem Scale (RSES-H): An alternative translation, structural invariance, and validity. Mentálhigiéné és Pszichoszomatika, 15(3), 259-275. DOI: https://doi.org/10.1556/ Mental.15.2014.3.7

Salmela-Aro, K., Kiuru, N., Leskinen, E., \& Nurmi, J.-E. (2009). School Burnout Inventory (SBI): Reliability and Validity. European Journal of Psychological Assessment, 25(1), 48-57. DOI: https://doi.org/10.1027/1015-5759.25.1.48

Salmela-Aro, K., Kiuru, N., Pietikäinen, M., \& Jokela, J. (2008). Does School Matter? The Role of School Context in Adolescents' School-Related Burnout. European Psychologist, 13(1), 12-23. DOI: https://doi.org/10.1027/1016-9040.13.1.12

Salmela-Aro, K., \& Newman, P. (2005). BBI-10 Koulu-uupumus-mittari [School Burnout Inventory]. Helsinki: Edita.

Salmela-Aro, K., \& Tynkkynen, L. (2012). Gendered pathways in school burnout among adolescents. Journal of Adolescence, 35(4), 929-939. DOI: https://doi.org/10.1016/j.adolescence.2012.01.001

Samdal, O., Nutbeam, D., Wold, B., \& Kannas, L. (1998). Achieving health and educational goals through schools-a study of the importance of the school climate and the students' satisfaction with school. Health Education Research, 13(3), 383-397. DOI: https://doi. org/10.1093/her/13.3.383

Samuels, P. (2016). Advice on Exploratory Factor Analysis. DOI: https://doi.org/10.13140/ RG.2.1.5013.9766

Schaufeli, W. B., Leiter, M., Maslach, C., \& Jackson, S. E. (1996). Maslach Burnout InventoryGeneral Survey. In Maslach, C., Jackson, S.E., \& Leiter, M.P. (Eds), The Maslach Burnout Inventory-Test manual (3rd ed.). Palo Alto, CA: Consulting Psychologists Press.

Schaufeli, W. B., Martínez, I. M., Pinto, A. M., Salanova, M., \& Bakker, A. B. (2002). Burnout and Engagement in University Students: A Cross-National Study. Journal of Cross-Cultural Psychology, 33(5), 464-481. DOI: https://doi.org/10.1177/0022022102033005003 
Seibert, G. S., Bauer, K. N., May, R. W., \& Fincham, F. D. (2017). Emotion regulation and academic underperformance: The role of school burnout. Learning and Individual Differences, 60, 1-9. DOI: https://doi.org/10.1016/j.lindif.2017.10.001

Simons-Morton, B., Crump, A. D., Haynie, D. L., Saylor, K. E., Eitel, P., \& Yu, K. (1999). Psychosocial, School, and Parent Factors Associated with Recent Smoking among Early-Adolescent Boys and Girls. Preventive Medicine, 28(2), 138-148. DOI: https://doi.org/10.1006/ pmed.1998.0404

Skaalvik, E. M., \& Skaalvik, S. (2009). Does school context matter? Relations with teacher burnout and job satisfaction. Teaching and Teacher Education, 25(3), 518-524. DOI: https://doi. org/10.1016/j.tate.2008.12.006

Skaalvik, E. M., \& Skaalvik, S. (2014). Teacher Self-Efficacy and Perceived Autonomy: Relations with Teacher Engagement, Job Satisfaction, and Emotional Exhaustion. Psychological Reports, 114(1), 68-77. DOI: https://doi.org/10.2466/14.02.PR0.114k14w0

Sorkkila, M., Aunola, K., \& Ryba, T. V. (2017). A person-oriented approach to sport and school burnout in adolescent student-athletes: The role of individual and parental expectations. Psychology of Sport and Exercise, 28, 58-67. DOI: 10.1016/j.psychsport.2016.10.004

Sorkkila, M., Tolvanen, A., Aunola, K., \& Ryba, T. V. (2019). The role of resilience in student-athletes' sport and school burnout and dropout: A longitudinal person-oriented study. Scandinavian Journal of Medicine \& Science in Sports, sms.13422. DOI: https://doi.org/10.1111/ sms. 13422

Szabó, É., \& Jagodics, B. (2016). Erôforrások és követelmények. Iskolakultúra, 26(11). DOI: https://doi.org/10.17543/ISKKULT.2016.11.3

Szabó, É., \& Virányi, B. (2011). Az iskolai kötődés jelentősége és vizsgálata. Magyar Pedagógia, 111(2), 111-125.

The Jamovi Project (2019). jamovi. Letöltve: 2019. 06. 01. https://www.jamovi.org

Tuominen-Soini, H., Salmela-Aro, K., \& Niemivirta, M. (2012). Achievement goal orientations and academic well-being across the transition to upper secondary education. Learning and Individual Differences, 22(3), 290-305. DOI: https://doi.org/10.1016/j.lindif.2012.01.002

Várnai, D. E., Jármi, É., Arnold, P., Demetrovics, Z., Németh, Á., Kökönyei, G., \& Örkényi, Á. (2018). A kortársbántalmazás (bullying) értelmezésének vizsgálata kvalitatív módszerrel - „Az iskoláskorú gyermekek egészségmagatartása” (HBSC) vizsgálat módszertanának kiegészítésére. Magyar Pszichológiai Szemle, 73(4), 519-539. DOI: https://doi. org/10.1556/0016.2018.73.4.1

Wang, M.-T., Kiuru, N., Degol, J. L., \& Salmela-Aro, K. (2018). Friends, academic achievement, and school engagement during adolescence: A social network approach to peer influence and selection effects. Learning and Instruction, 58, 148-160. DOI: https://doi.org/10.1016/j. learninstruc.2018.06.003

World Health Organisation (2018). International statistical classification of diseases and related health problems (11th Revision). Letöltve: 2019. 06. 16. https://icd.who.int/browse11/l-m/en 


\title{
EXPLORING THE STUDENT BURNOUT SCALE USING HUNGARIAN SAMPLE
}

\author{
JAGODICS, BALÁZS - KÓRÓDI, KITTI - DR. SZABÓ, ÉVA
}

Background and goals: Due to the prevalence of burnout-syndrome, research on this phenomenon is becoming increasingly important. As a result, beside examining the burnout-syndrome among adults, it is also important to explore the problem in the schools. The aim of our research is exploring the structure of the Hungarian version of the Student Burnout Inventory (Salmela-Aro et al., 2008, 2009).

Methods: The participants were Hungarian primary $(N=337)$ and secondary school students $(N=738)$, between the age 13 and $18(M=15,3$ years, $S D=2,01)$. We checked the structure of the questionnaire, the internal consistency and the connections between student burnout and other demographic and psychological factors.

Results: According to the exploratory and the confirmatory factor analysis, the three-factor structure of the questionnaire is the same as the original, which consists of three subscales: emotional exhaustion, cynicism and sense of inadequacy. There was no difference between the the boys and the girls in the overall burnout score, and in the case of school-type the scores of primary and secondary school students differed only on the subscale of cynicism. The academic achievement correlated negatively with the burnout, as well as the selfesteem, school attachment and mastery-approach goal orientation. The avoidance goal orientation showed positive correlation with the overall burnout score. The hierarchical regression analysis established that the subscales of the Student Burnout Inventory and the dimensions of the goal orientation could predict the level of the self-esteem, with 50,3\% of the explained variability.

Conclusion: Based on the results, the Hungarian version of the Student Burnout Inventory with 8 items is appropriate for measuring student burnout, and for separating the symptoms of emotional exhaustion, cynism and sense of inadequacy. Based on the Cronbach-alfa indicators, the reliability of two of the subscales are only acceptable. Therefore we advise to use the questionnaire as a unidimensional scale. The questionnaire may be suitable for further exploratory research or can be an useful tool for school psychologist as well.

Keywords: student burnout, self-esteem, goal orientation, school attachment

A cikk a Creative Commons Attribution 4.0 International License https://creativecommons. org/licenses/by/4.0/) feltételei szerint publikált Open Access közlemény, melynek szellemében a cikk bármilyen médiumban szabadon felhasználható, megosztható és újraközölhetô, feltéve, hogy az eredeti szerzô és a közlés helye, illetve a CC License linkje és az esetlegesen végrehajtott módosítások feltüntetésre kerülnek. (SID_1) 